\title{
6 Facing the queer migrant in Nordic Noir
}

\author{
Louise Wallenberg
}

While Nordic Noir - at times referred to as Scandinavian Noir - has become an internationally powerful and evocative concept or phenomenon that encompasses literature, film and television, its existence is rather recent, at least as a definable, critical concept. ${ }^{1}$ Before international audiences and critics 'discovered' that there was a specific regional aesthetics and mode of narration attached to the crime novels (and later, televised series) coming out of the Nordic countries, it was not considered as anything other than just ordinary Danish, Swedish, Norwegian, Finnish or Icelandic crime ${ }^{2}-$ at least by the Nordics themselves. ${ }^{3}$ And while 'Nordic' and 'Scandinavian' as geographical and cultural categorisations and labels - in most international discourse are used indiscriminately, it should be pointed out that they do differ in terms of geography and in terms of inclusion: while 'Nordic' as a geographical label encompasses all five countries, 'Scandinavian' encompasses only three of them: Denmark, Norway, and Sweden. ${ }^{4}$ Yet while Nordic and Scandinavian differ from one another - the former being more inclusive than the latter - they are, of course, intimately related, not least because they share a long, and at times complicated, history. ${ }^{5}$ Linguistically, the Scandinavian languages are closely related - especially in written form - and culturally, all five Nordic countries share many traits and traditions. Further, these countries share a similar political history, with a strong Social Democratic (or at least liberal) governance starting in the early twentieth century, a governance mostly characterised by the will to create a modern, equal society informed by an inclusive welfare system. As we have reached the new millennium, these welfare states are slowly being dismantled, due much to the fervent attacks (and apparent mesmerism) coming from nationalist, popularist and far-rightist ends. There is, however, one more aspect that unites the two concepts 'Nordic' and 'Scandinavian': both refuse any national claims.

In this chapter on Nordic Noir, I will concentrate on one Nordic country in particular: Sweden. I will investigate how characters who are queer and either asylum seeking refugees, (im)migrants, or in other ways ethnically different, are currently being represented and negotiated in contemporary 'Swedish' Noir. The characters I will be focusing on can all be described 
as Scandinavian or Nordic others - taken that the Nordic countries for a long time remained ethnically homogenous. ${ }^{6}$ While the productions examined may be labelled 'Swedish', it is important to point out that they are to some extent also 'transnational'. Following Elke Weissmann, I use transnational rather than 'global' (an all-too-inclusive term), since transnational 'emphasise[s] the intersection and interconnections between the national and the global, and indeed the co-existence of homogenisation and heterogenisation' (Weissmann 2018: 121). ${ }^{7}$ The transnational - especially in relation to Nordic Noir - may also propose a narrower position that regards a 'phenomenon as an issue involving two or more countries and not a global, worldwide view' (Toft Hansen et al. 2018: 9). This is often the case with Nordic Noir productions - as with most Euronoir productions. Most Nordic Noir, from the 'Wallander-films' (1995-2013) to the 'Martin Beck-films' (1997-2018), Bron I-IV/The Bridge I-IV (2011-18) and Midnattssol/ Midnight Sun (2016), are transnational co-productions that on a narrative level serve to negotiate and identify cross-national and cross-cultural realities and geopolitics. ${ }^{8}$ In fact, the transnational aspect of Scandinavian (and Nordic) cinema has a long history: from the very breakthrough of cinema in the Nordic region in the late nineteenth century, it has relied on joint efforts in terms of both financing and artistic creativity. As Anne Bachmann has shown, it was very common in the early twentieth century for Danish, Swedish, and Norwegian film workers to collaborate; hence the silent cinema of the North was indeed Scandinavian (see Bachmann 2013).

The focus here is on three recent television dramas that have been both marketed and perceived as part of Nordic Noir, and all of which were partly made for the Swedish public broadcasting network (Sverige Television (SVT)): Bron IV (2018), a series which, like its predecessors Bron I-III (2011-2015), was produced for both the SVT and the Danish equivalent, the Danish Public Broadcasting network (DR); Innan vi dör/Before We Die (2017, SVT); and Midnattssol/Midnight Sun (2016, SVT and Canal+). All three include characters that are queer and migrant - hence, characters that are positioned as 'other' (even when they are 'inside'). But, as is so often the case with Nordic Noir and with crime fiction in general, otherness is pluralistic. It is not only the queer migrant that constitutes the 'other' in relation to the supposedly 'non-other', that is, the 'normative' (culturally and ethnically) insider - so do a variety of characters. Queerness in combination with ethnic 'otherness' makes queer migrants still more 'other', yet in all three dramas the most 'other' is presented in a complex manner that refuses simplistic stereotyping. He (in all three productions the queer migrant is male) is portrayed as a multifaceted person with whom we are invited to feel strongly for or even identify with. Hence, the queer migrant is facing us as spectators, calling out for an affective engagement. ${ }^{9}$

My aim in what follows is first to explore the tradition of Nordic Noir (and its deviances) and its relation to the current migrant crisis, then to examine the representation of the 'queer migrant' in the three productions. It 
should be noted that while the Nordic countries are close culturally, geographically, and linguistically (to a certain extent), their immigration politics and handling of immigrants and refugees have differed - and to some extent still differ - from each other. Their respective welcoming of migrants contra their sturdy immigration restriction has fluctuated over the years, but what unites them today is the perceived threat that migrants and (im)migration are posing to the status quo of the Nordic region. The predominant mode of Nordic politics, as in other parts of the Western world, appears today to be one of fear: fear of the 'other', the Non-Western, an 'other' who - the more popular discourses declare - is bringing illegality, criminality, and terrorism. Even in Sweden, often hailed as the most progressive of the Nordic countries (adoption rights for gay and lesbian couples became law in 2003, insemination rights for lesbians were legalised in 2005, and same-sex marriage law was passed in 2009), there has been severe criticism of how the Migration Agency has handled a string of cases of queer asylum seekers in the country, most notably from voices in the LGBTIQ+ community. ${ }^{10}$

While representations of vulnerable (im)migrants and refugees have populated Nordic Noir for some time (like those of violent and criminal immigrants), the genre has seen very few queer characters. Hence, queer hacker Lisbeth Salander in crime novelist Stieg Larsson's Millennium trilogy constitutes a most welcome exception, as do the two teenage lovers in the Norwegian Noir series Øyevitne/Eyewitness (2014, NRK). As for queer visual representation in general, Nordic film and television fiction is inclusive to some extent, although statistics show that queer representations on screen are still embarrassingly sparse. ${ }^{11}$ In the case of documentaries dealing with queer and trans-related experiences and stories in Nordic media, most of which are broadcast on television, the number of representations has most certainly been higher (see Wallenberg 2015).

\section{Nordic deviations}

At the centre of Scandinavian Noir, as of Nordic Noir, is often a lonesome, melancholic, and troubled male police detective struggling to keep his personal life together while fighting crimes in a welfare society that is becoming increasingly tainted by social problems. ${ }^{12}$ At the root of this societal change is the fact that common solidarity is no longer a given - in tandem with the social safety net becoming more and more weakened. In many ways, the policeman with whom the readers are positioned to sympathise (although he may not be that easily likeable) is both the interpreter and the bearer of a cultural anxiety, or anxieties, that extends far beyond himself (see Robinson 2014). This makes Nordic Noir a realist genre: it is close to existent societal problems and tries both to represent and comment on them. A second characteristic is the sombre setting: most of these novels unfold in milieus that are dark, uninviting, and cold, and the colour saturation tends to draw towards blues, browns, and greys. Hence, the famous Nordic light - which is 
never-ending during the summer months - is exchanged here for a November darkness that is constant.

While these are characteristics that have come to define Scandinavian (and Nordic) Noir, there is one more 'trait' that demands to be brought up: the genre's willingness to play with - and extend - its format, making Nordic Noir constantly flexible and malleable (Forshaw 2012: 3). In this way, it refuses any homogenising classification: there are differences in gender, in the profession of the crime-solving character, in the setting, and in the amount of realism. Hence, the genre welcomes deviances, and few Nordic Noir productions fall unproblematically under the qualifications laid out previously. This is true for the three chosen television series under discussion: while all are classic police dramas and point to larger social and cultural anxieties, only two of them make some use of a grey, rainy and somber setting: Innan vi dör and Bron IV. Midnattssol, as the title indicates, takes place in the very north of Sweden, and when the summer is at its brightest and longest, that is, when the sun never goes down. Midnattssol also expands the genre in terms of location: whereas most Nordic Noir productions play out in the city, Midnattssol takes place in a small community, set in the empty vastness of the North, near the border with Finland - hence, a vast and always sunlit landscape as scenery is replacing the dark, crowded, and stressful setting of the urban environment. In addition, Midnattssol challenges the emphasis on realism that characterises so many crime dramas by relying on the supernatural, intimately tied to nature. In fact, the supernatural has become an ingredient in Nordic noir: whereas the Scandinavian crime novels coming out of the 1970s, 1980s and 1990s were indeed socially realistic, the recent novels and television dramas often assume a more playful attitude towards the supernatural. Both Midnattssol and Jordskott (SVT, 2015-17) make use of nature as threatening, untrustworthy, and avenging.

While there existed a crime tradition in Scandinavian film and literature that preceded the 1960s, it is only in the 1960s, with the Swedish author duo Maj Sjöwall and Per Wahlöö and their novels about police detective Martin Beck and his colleagues, that Scandinavian crime became known outside of its own regional borders. ${ }^{13}$ Between 1965 and 1975, Sjöwall and Wahlöö cowrote no less than ten novels - all containing references to real events while applying a more realist style than was common at the time. Early on, their novels were translated into several other languages, hence outlining Scandinavian crime, defining 'the shape of Scandinavian crime fiction, making it recognisable to readers beyond the Scandinavian countries, and creating a set of expectations' (Arvas and Nestingen 2011: 4). Most of the SjöwallWahlöö novels have been adapted for cinema, and later, their characters have inspired new films loosely based on their novels. All in all, eight of their ten novels were turned into films in Sweden, produced between 1967 and 1994. Between 1997 and 2018, a series of thirty-eight films known as the 'Martin Beck-films' (and loosely connected to the original books) was made for television (TV4). The first of these films kicked off the transnational 
production constellation that today defines Nordic Noir (the films were backed financially by Sweden, Denmark, Germany, Finland and Norway, and initially also France).

While most of the Beck-films have focused on crimes such as gynecide, drug trafficking, prostitution, MC gang rivalry, and underground criminality, two out of four films made in 2018 centred on issues dealing with problems and threats attached to (im)migration: in Ditt eget blod/Your Own Blood (2018, Sweden, dir. Mårten Klingberg), Beck has to deal with terrorist threats with direct connections to the Middle East, and in Den tunna isen/ The Thin Ice (2018, Sweden, dir. Mårten Klingberg), with solving a murder that is the consequence of a violent resistance towards war refugees in a suburb outside of Stockholm. The inclusion of (im)migrant representations is also present in the many films made based on Henning Mankell's crime novels about detective Kurt Wallander, the Wallander series (1994-2013). Here, most (im)migrants are presented not only as vulnerable, but as victims of hate crimes and exploitation: in the four-part television series Mördare utan ansiket/Faceless Killers (TV4, 1995) a refugee camp is put on fire and a Somalian man is murdered; in Afrikanen/The African (2005, Sweden, dir. Stephan Apelgren) an African man is found dead on a train from Poland arriving in Sweden; in Täckmanteln/The Cover (2006, Sweden, dir. Anders Engström), ten migrants are found dead in a container in the middle of the forest; and in Saknaden/The Missing (2013, Sweden, dir. Agneta FagerströmOlsson), a Moldavian woman who has been forced into prostitution is murdered. These all take up the haunting and precarious issues of human and sex trafficking, violent (and latent) racism, and deadly xenophobia. These representations have served to bring 'Europe's minorities to the forefront of public visibility and often reduce[d] their identity to that of perpetrators or victims of violence' (Celik 2015: 5). In the three televised dramas under discussion, the migrants are composed of recognisable facets from earlier Nordic Noir productions - that is, as victims and/or criminals - but other aspects are also added to their personas. All three constitute fuller, more complex, migrant portraits, contributing to give the 'migrant' and the 'other' a multifaceted face. In this way, these three productions challenge the existing limited and generic images of migrants and serve to make them buman. ${ }^{14}$

\section{Queer migrants in Innan vi dör, Bron and Midnattssol}

Innan vi dör/Before We Die is a ten-part television series produced for Swedish Public National Television by B-Reel and co-produced by German ZDT and Filmregion Stockholm-Mälardalen/Filmcapital. It centres around a woman detective, Hanna Svensson (Marie Richardsson), and her thorny relationship to her son Christian (Adam Pålsson), who - without her knowledge - is working for her colleague and lover as an infiltrator in a mafia family. The focus of their investigation is the Mimica family. The Mimicas are of Croatian origin and escaped the Balkan wars in the mid-1990s 


\section{Louise Wallenberg}

after a massacre killing many of their family members, including the father. In Stockholm, they have established a small, cosy restaurant and they use it as a cover for their criminal activity involving drug and weapon trafficking. The family is headed by the mother, Dubravka Mimica (Malgorzata Pieczynska), and working for her is her son Davor (Alexej Manvelov) and Stefan (Peshang Rad), who lost his entire family in the massacre and whose father was a friend of Davor's father.

Having spent two years in prison for drug possession and selling, Christian and Stefan have become friends. As they are released, Christian takes up a job as a dish washer at the Mimica restaurant (a job that includes helping Stefan collect drug money from dealers). Christian is well liked by the family, but Davor will soon come to suspect Christian. Yet he is slickly grooming Christian, showing appreciation and at one point giving him an expensive watch, only to threaten him the next. Davor is early on presented as coldhearted and psychopathic, as he alternately tutors, charms, and menaces Christian. In episode two, Davor (who has established himself as the brain behind the family's plan, 'Operation Krajina', to take over the entire drug business in Stockholm and beyond) surprises us: in the opening of a scene he is shown in a medium-close up, naked and panting - it is clear that is he in a post-coitus situation. The camera then pans to the left, disclosing his male lover next to him. As he gets ready to leave the apartment, he demonstrates affectionate love for Markus (Erik Johansson); hence, his character breaks with the first characterisation of him, informed by the stereotypical male Balkan migrant as heartless and criminal (a stereotype that has marked Scandinavian, and other European, crime fiction since the Balkan wars in the 1990s). Several scenes show him as loving and caring towards Markus, mostly in Markus's flat or in the car - yet when Markus decides to surprise him at the restaurant, expecting a romantic dinner with him, Davor makes sure to have Christian escort him home. As Markus calls Davor from his cell phone during the ride, Christian realises that they are a couple. A few days later, when Davor does not turn up for a family meeting, Christian seeks him at Markus's place and finds out that a night out at a gay club has gone very, very wrong. He finally finds Davor - heavily sedated and raped - in a remote trailer park on the far outskirts of Stockholm and saves him. This painful incident will deepen the relationship between Davor and Christian, and instead of distancing Christian from him (because he knows his secret), Davor now starts involving him in his operation. From now on, Davor seems only to trust Christian - his interactions with him become affectionate, and it seems as if Christian reciprocates his affection. As the intrigue escalates and the narrative focus is placed on 'Operation Krajina', Markus is omitted, and it is instead the relation between Christian and Davor that is highlighted. As they get closer to the take-over, however, Christian's situation becomes unbearable, and, after he has been forced to kill Stefan, whom Davor now suspects is a rat, he wants out. At the end, the story is about these two men: Davor realises who Christian really is and sets out to kill him. There is a 


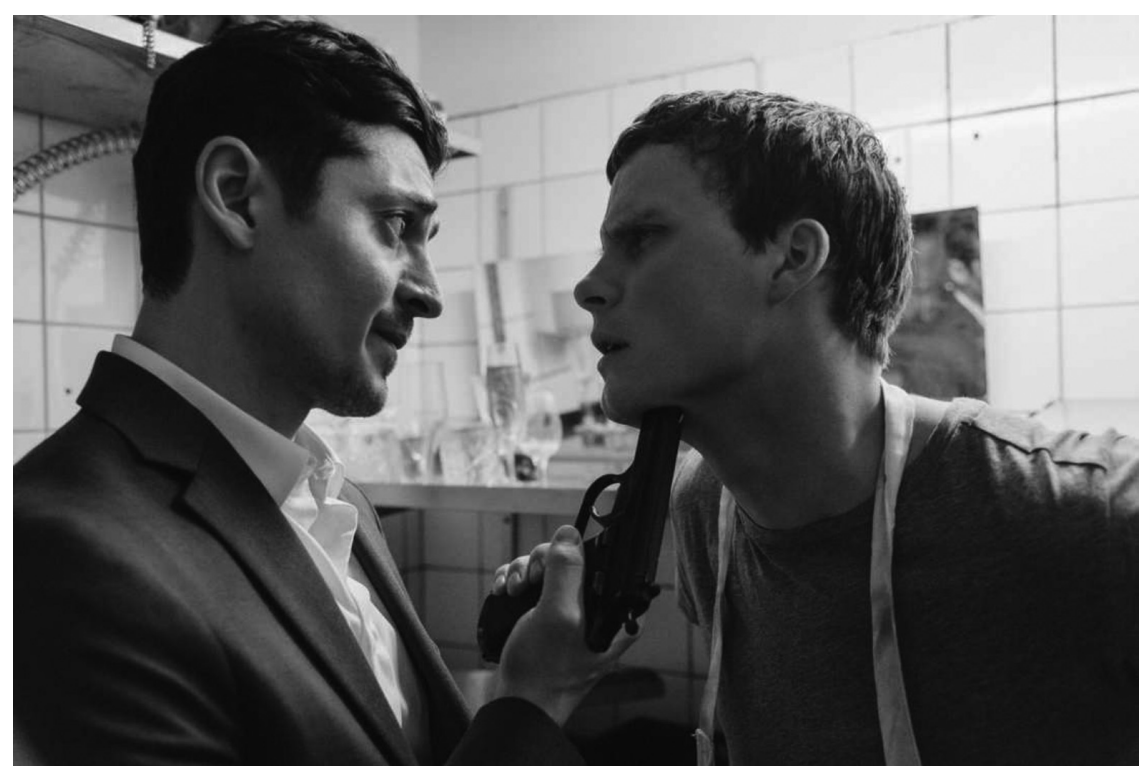

Figure 6.1 (Davor) Alexej Manvelov and Christian (Adam Pålsson) in season one of Innan vi dör/Before we Die (2017)

Source: Innan vi dör/Before We Die (2017) (C) Swedish Television (SVT). www.aftonbladet. se/nojesbladet/tv/a/VRp9gJ/klart-for-en-ny-sasong-av-innan-vi-dor-i-svt (accessed February 17 2020).

final shoot-out, set on a cliff in the Stockholm archipelago in bright sunlight. Following the conventions, the criminal has to die, but it is not Christian who is doing the killing - it is Hanna, who now steps in to protect her son.

Davor is a most compelling and complex character, and although he is a cold-hearted criminal, the series makes him utterly human. He is a war victim who has managed to make himself a life in a country in which 'Slavophobia' is spread, and he is a caring lover who together with Markus is vulnerable, loving, and insecure. Davor the criminal is moving through a landscape coloured by racism and homophobia, but Davor the lover is human, vulnerable - the Davor he would be, had it not been for the circumstances in which he is caught. As Hanna pulls the trigger, his eyes express sad relief more than anything else.

Bron is a co-production made for SVT and DR, and, after Forbrydelsen/The Killing (DR 2007-12), it is probably the most popular Nordic noir that has been screened both within and outside of the Nordic region. The series focuses on the collaboration between a female Swedish police detective and a male Danish police detective as they try to solve a series of hideous murders that are connected to both countries (the bridge referred to 


\section{Louise Wallenberg}

in the title is the actual sixteen-kilometre-long bridge between Malmö and Copenhagen (inaugurated in 2000)). The first season premiered in 2011, the second in 2013, the third in 2015, and the last, and final, season - Bron $I V$ - premiered in early 2018 .

The final season in particular is highly reflective of its pertinent political and social situation - a situation that since the first season has slightly changed in some aspects and been reinforced in others. Between 2012 and 2016, the number of Syrian refugees seeking asylum in Scandinavia (and Europe) increased steadily, and as a consequence so did the general consciousness about the refugee crisis: the crisis was covered in the media constantly, and politicians worked hard to unite around immigration policies. ${ }^{15}$ This situation affected the writing team of Bron, and so, in the final season, this crisis is included as an unavoidable presence. As the series' creator Hans Rosenfeldt puts it:

if we were going to do a cross-border thing for the fourth time ... we cannot just ignore the fact that the bridge has a slightly different meaning today than it had in 2011 when it was ... a kind of road to freedom and to Europe ... uniting and now it is actually a border. ${ }^{16}$

In Bron IV, the refugee crisis, involving thousands, millions, of people, is being represented by one character: a gay Iranian man in his late twenties. The season opens, like in previous seasons, with a brutal murder: a middle-aged woman is found dead outside Copenhagen; she has been buried standing up, only her head above the ground, and stoned to death. The Danish-Swedish detective duo Saga (Sofia Helin) and Henrik (Thure Lindhardt) soon find out that the victim is the head of the Danish Immigration Board, and little by little they are led to an Iranian refugee, Taariq (Alexander Behrang Keshtkar), who is hiding in Copenhagen after he has been denied a residence permit. Initially he is unwilling to help out, which makes him suspect, but one soon learns that he is afraid that his involvement will put himself at risk of deportation. In fact, Taariq turns out to be a just and caring person, and although his is only a supporting role, his character is central to the plot and his presence and impact definite. While Bron presents a myriad of characters that are either suspect and/or not very likeable (the detective team included), Taariq is the one character the spectator is made to feel for, and with. He is also a victim - he dies, and while his death is completely unnecessary, it is expected: following narrative conventions, the vulnerable and most likeable character is bound to die. But his death is painful to watch, much more painful than all the other horrendously sadistic butcheries that occur in Bron. It is painful because Taariq is a victim of outrageous circumstances - first, living under death threat as a gay man in Iran, and later, forced into hiding (and then executed) in a country he hoped would be his safe haven. Hence, Taariq is portrayed as doubly vulnerable - vulnerable because of his refugee status and because of his sexuality. By contrast, Davor chooses to expose his vulnerability only in relation to his lover; he manages to put that vulnerability on the 
side when 'at work'. The two characters clearly differ in many aspects, one of them being their different vulnerability. Following Judith Butler's discussion of precariousness (Butler 2004a), one may contend that whereas Davor is vulnerable in the way he is at risk of injury, Taariq's situation is precarious since he is in imminent danger of perishing, that is, of being killed.

Midnattssol/Midnight Sun, a French-Swedish co-production (SVT and Canal+), takes place in a small village set north of the ore-mining town Kiruna, which is situated in the most Northern part of Sweden, in a large district called Norrland (meaning North land). ${ }^{17}$ As mentioned, the series breaks with the dark and sombre urban setting of most Nordic Noirs, and instead makes use of the bright summer months - months when the sun never goes down. ${ }^{18}$ Half of the scenes take place during the night - in bright sunlight - and the small investigating team seems never to get any sleep. The outsider, flown in from the South, has troubles coping with the constant sunlight, but the others, born and bred up North, handle it without any problem. Still, there is no question that Midnattssol/Midnight Sun conforms to the Nordic Noir genre: we have the insecure and troubled investigator (not a policeman but a prosecutor), who is a single father with a complicated relationship with his teenage daughter, and who is also struggling with his own identity. There are the more than gruesome and bestial series of murders - and just like in Bron, the limits for how macabre a murder can get are surpassed time and time again. The increasing problems caused by the dismantling of the welfare state, so present in most Nordic Noirs, is here palpable: the entire town of Kiruna is being dismantled and moved to another geographic area, since the mine has caused severe damage to the ground on which Kiruna rests. Also, the confrontations between Swedes and Samis - an indigenous group that has suffered severe oppression from the Scandinavian states during the past centuries - is becoming increasingly violent, with Swedes flaunting racist attitudes towards the Sami people.

The series opens with the murder of a French citizen, tied to one of the wings of a helicopter propeller, and decapitated by the strong rotation as the helicopter takes off. The nationality of the victim prompts the Swedish police to get the French involved, and Paris-based detective Kahina Zadi (Leila Bekhti) is sent up North to investigate the crime together with the local chief prosecutor Rutger Burlin (Peter Stormare), who is assisted by the tentative and insecure prosecutor Anders Harnesk (Gustaf Hammarsten). Like Anders, Kahina has her demons: she has a teenage son whom she was forced to leave behind in Algeria just after his birth, and she struggles with her identity as a Berber-French woman. From the first episode, it is clear that Kahina is injuring herself deliberately with sharp objects. While the interesting relationship is that between Kahina and Anders - she is a reserved but talented and experienced detective working for the Office Central pour la Répression des Violences aux Personnes (OCRVP), he is a goodhearted red-tapist with little experience of murder - they will never end up as lovers. They will at one point however share the same lover, Thor (Richard 


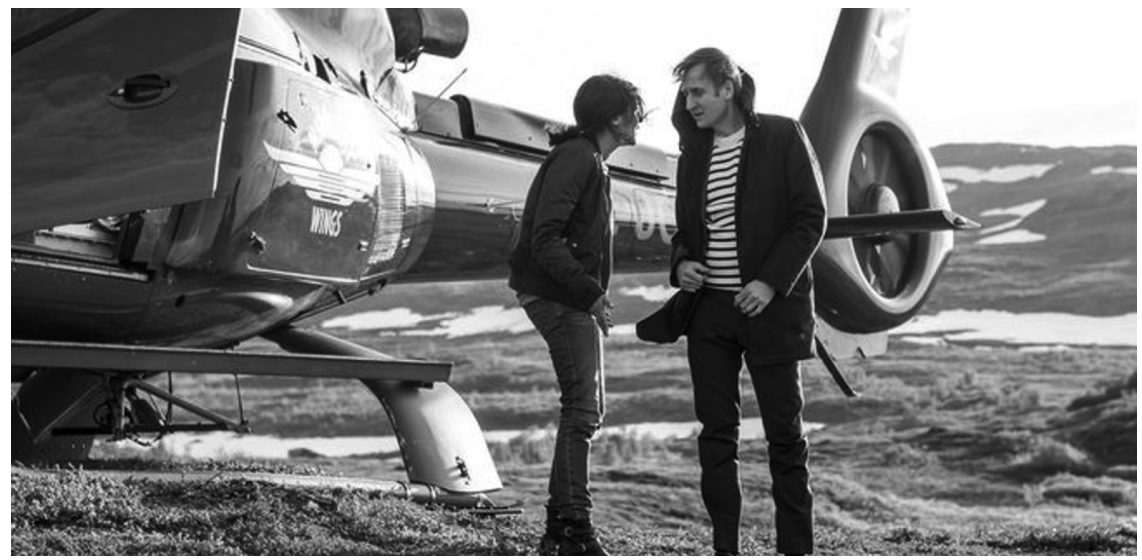

Figure 6.2 Berber/French detectiveKahinaZadi(Leïla Bekhti) and Swedish/Sami prosecutor Anders Harnesk (Gustaf Hammarsten) in Midnattssol/Midnight Sun (2016)

Source: Midnattssol/Midnight Sun (2016) (C) Swedish Television (SVT) and Canal+. www. expressen.se/noje/blogg/tvbloggen/2016/09/27/forsta-titten-sa-bra-ar-midnattssol-i-svt/ (accessed February 17 2020).

Ulfsäter). Both are struggling with their identity, and both experience being considered 'other' - in both cases in terms of ethnicity, and also in terms of sexuality for Anders. He is, we find out in the second episode, 'half-Sami, half-Swede'. And while Kahina can only pass as 'Algerian' (although she is a Berber and thus, like a Sami, linked to an indigenous people), Anders can pass as a Swede - yet he, too, is an 'other' ethnically. Swedes who know he is half-Sami regard him as Sami, and the Samis - including his Sami mother see him as a Swede. In this sense, he is half, neither one nor the other.

When Anders finds out about Kahina and Thor, it saddens him so much that he ends the relationship with Thor - and he openly expresses to both of them how much they have hurt him. In conveying his emotions, he shows vulnerability, but also strength, as he tells Thor that he 'will never accept being a footnote in someone else's story'. His openness further touches Kahina in a way that will make her confront her own demons. Yet, as their investigation reaches its end, and he takes her to the airport, they both realise that it is over. She is off to Paris, he stays in Norrland, and they will most probably never meet again. The impact they have had on each other's life, however, is unmistakable: they have become stronger as people and, with the help of the other, each has reached self-acceptance.

Whereas Anders is not a migrant as in a person who migrates, he is viewed as other because of his dual ethnicity. He belongs to an ethnic minority, and is being treated as one - by the dominant group. He is also gay, and is 
about to come out as gay - after having forced himself to pass as straight. He is emotionally vulnerable, but he shows enormous strength in explicitly expressing how hurt he is by the betrayal, and by still cherishing his professional and personal relationship with Kahina. The two 'others' - the Sami and the Berber - team up, and they will find comfort and understanding in each other.

\section{Conclusion}

Anders, Davor, and Taariq have little in common except for being ethnically and sexually 'other'. Their situations are worlds apart: as a child Davor survived and escaped a war, and circumstances have turned him into a criminal; while he stresses that the family must always speak and 'be' Swedish, he is always other, always an (im)migrant. Taariq, a refugee in hiding after his application for residency has been denied, finds himself in an unbearable and precarious situation, and his death highlights the situation for many queer refugees: if not granted permission to stay, and sent back to their country of origin, they risk 'perishing', that is, death. Anders is 'other' because of being half-Sami, half-Swede, and he experiences discrimination and racism daily, both by the Samis and by the Swedes. All three are represented as vulnerable, and all three are not only likeable as characters: each series makes an effort to present complex characters with whom the spectator can also can identify. They face the spectator who is forced to face them back. The affective engagement these three characters manage to evoke is, I believe, of immense importance. Although fictional characters created for the purpose of suspense and entertainment, they each make the migrant a human subject demanding recognition. Whereas actual migrants and refugees are 'hidden' behind statistics and press images, often showing innumerable faceless refugees moving in large groups, these three characters - in their vulnerable position as 'other' - make possible a form of Levinasian 'face-to-face' encounter that both 'orders and ordains' the spectator to feel and care for them.

Vulnerability, as a new political language emanating from the severe refugee crisis (and also from the \#MeToo movement), is ambiguous and troubling. It is a difficult concept because it connotes dependence and weakness as well as victimisation. As Anu Koivunen et al have pointed out, ' $[\mathrm{m}]$ aking injustices visible may result in reinforcing ... assumptions about vulnerability as non-agency' (Koivunen et al. 2018: 5). The three characters focused upon here are vulnerable, and to a certain degree their representation appears to reinforce the image of the migrant as a victim, yet they are not without agency. While the discourse of vulnerability can serve to support paternalistic, racist, misogynist, homophobic, antifeminist agendas, these three representations instead work powerfully against them. 


\section{Notes}

1 Nordic Noir has spread into other visual fields beyond film and television, including fashion photography: a Nordic Noir aesthetic became popular in fashion spreads in various high fashion magazines in the early-to-mid 2010s.

2 According to Audun Engelstad, Nordic Noir was 'discovered' sometime between 2009 and 2011: in 2009, the three novels by Stieg Larsson - the Millennium trilogy - were released as theatrical movies (and later reedited into a six-episode television series), and in 2011 Jo Nesbøs's Hodejegerne/Headhunters was adapted for the big screen. Hence, Nordic Noir emerged as a concept in conjunction with the international success of a few screen versions, some of which were adapted from crime novels, some written directly for television. See Engelstad (2018: 26-7).

3 Regional rather than national, since 'Nordic' encompasses all Nordic countries.

4 Barry Forshaw points out the specificity of each culture, writing that 'despite the proximity to one another of the various Scandinavian countries, their individual identities are remarkably pronounced. The patience generally shown by the inhabitants when the British and Americans lazily lump all the Scandinavian nations together is both surprising and admirable'. See Forshaw (2011).

5 Southern Sweden was Danish up until 1658, Finland was part of Sweden up until 1809, Norway and Denmark were in a union (together with Iceland, the Faroe Islands, and Greenland) up until 1814, and between 1814 and 1905 Norway was in a union with Sweden.

6 It was not until after the mid-twentieth century that the populations started to become more heterogenous, and this change was greatly due to the immigration of labour from southern Europe. Later, political and war refugees from South America, the Balkans, and the Middle East sought their way up North, and, in more recent times, the largest proportion of immigrants has consisted of war refugees from Syria and Afghanistan together with neighbouring countries.

7 See Esser (2002, 2007).

8 In terms of co-production, Bron/The Bridge IV is a prime example of how even Nordic Noir has become transnational in terms of funding: it involved as producers the Swedish film production companies Filmlance and Nimbus Film (for the Swedish and Danish public service institutions SVT and DR), as well as ZDF (Germany) and NRK (Norway). It was co-financed by Film in Skåne, YstadÖsterlen Filmfond, the Copenhagen Film Fund, as well as Nordvision. See Toft Hansen et al. (2018: 8-9).

9 I have searched for lesbian migrant representations in Nordic Noir but found none. Could it be that the image of a lesbian migrant is one form of 'othering' too many? Or is it that representations of men are still presumed to be more 'interesting' than those of women?

10 See, for example, www.rfsl.selaktuellt/forsamrat-lage-for-hbtq-flyktingar/ and www.migrationsinfo.se/migration/sverige/hbtq-flyktingar/. In most instances, the criticism centres on the pressure that asylum seekers feel they are under to 'perform' their sexuality when interacting with the Agency in order to convince it of their queerness. See www.qx.se/tag/hbtq-flykting/ (accessed 1 August 2019). In Norway, much criticism has been directed against the government and a system that discriminates against queer family immigration. See www.vg.no/ nyheter/innenriks/i/4d8rjG/syrisk-flyktning-faar-ikke-gjenforenes-med-kjaer esten-i-norge-systemet-diskriminerer-homofile?utm_source=inline-teaser $\sigma$ utm_ content $=j$ PE9rw (accessed 1 August 2019).

11 See, for example, Swedish Film Institute 2015. Only one per cent of all characters represented in all feature-length films produced in 2014 in Sweden were queer or, as SFI would have it, 'homo- or bisexual' (in the original Swedish: 'En 
procent av alla karaktärer är homo-eller bisexuella'). The report also includes a commentary on the next-to-nonexistent representation of transsexual characters in the films made in 2014. Not surprisingly, the report was met with criticism for its failure to include queer and transgender in its survey.

12 While the main protagonist started out as a man, over the years a few female characters have expanded the genre: in Swedish author Liza Marklund's work, the main protagonist is Annika Bengtzon, a journalist solving the most horrid crimes (and who is clearly a great asset to the police), and in Norwegian author Anne Holt's work, the protagonist is the crime detective Hanne Wilhelmsen, who, adding to her 'uniqueness', is an out-lesbian.

13 Norwegian crime author André Bjerke, who published three popular crime novels in the mid-1940s, and Swedish authors Stieg Trenter and Maria Lang, whose work became increasingly popular with the domestic audience in the 1940s and early 1950s, are worth mentioning here. As for crime on film, Arne Mattsson's five films about the married detective duo the Hillmans, made between 1958 and 1963, and based on the manuscripts written by crime writer Folke Mellvig, deserve a mention.

14 Interestingly, the amount of media coverage of these three series in general, and of the three queer migrant characters in particular, differed markedly between mainstream media and LGBTIQ+ media. Whereas the 'straight' media devoted much space to them (and especially, it must be pointed out, to Alexej Manvelov who plays Davor), there was almost next to nothing reported in the queer media. One possible reading of this silence is that the latter disregarded these representations largely because the characters were all played by straight actors. Since 2014, a discussion about who should be allowed to play whom has surfaced in the media, leading to the rather absurd question of whether only straight cis actors should play straight cis characters, and queer and/or trans actors only play queer and /or trans characters. See, for example, Blomquist (2014) and Therese Färsjö (2015).

15 In the Nordic countries, as in other countries in the EU, the highest numbers of refugees seeking safety occurred in 2015 and 2016, but since then the numbers have decreased drastically: in 2018 only 18,045 refugees sought safety in Sweden; 3,120 in Denmark; 2,530 in Norway; 2,945 in Finland; and 730 in Iceland. See the UN Refugee Agency Report from 2018: https://data2.unhcr.org/ en/documents/download/68318\#_ga=2.137077296.1265214860.15671451162032067315.1567145116 (accessed 20 August 2019).

16 In an interview with Benji Wilson at the British Film Institute in 2018. See www. youtube.com/watch? $v=9 M j 6 w j 4 L E J c$.

17 Kiruna, the series points out, is located some $250 \mathrm{~km}$ north of the Polar Circle, and, as chief prosecutor Burman tells his small crew, Norrland takes up a fifth of Swedish territory.

18 As the female protagonist Zadi arrives in Kiruna in the first episode - and up to here the cross-cutting of scenes between Kiruna and Paris (shot at the same time) has clearly indicated that whereas the Parisian summer night is rather dark, the summer night in Norrland is as bright nighttime as it is daytime - she asks: 'When does the sun go down?'. The answer she receives is: 'In a few weeks'. 